\title{
O Artigo 1228 do Código Civil e os Deveres do Proprietário em Matéria de Preservação do Meio Ambiente
}

\section{Bruno Miragem*}

1. Introdução. 2. O novo Código Civil e a definição jurídica de propriedade. 2.1. A propriedade como fonte de deveres jurídicos; 2.2. A propriedade como fonte de deveres jurídicos em matéria de preservação do meio ambiente. 3 . Definição legal de propriedade e os deveres do proprietário em matéria preservação do meio ambiente. 3.1. Deveres do proprietário e legislação ambiental. 3.2. Deveres do proprietário e o direito de indenização. 4. Conclusões.

\section{INTRODUÇÃ.O}

A propriedade, antes de um conceito jurídico, é um conceito cultural. Certamente um dos debates mais presentes no direito civil contemporâneo e, de modo geral, na própria ciência do direito desde algum tempo, diz respeito à exata dimensão do conceito de propriedade e suas diversas repercussões em matéria da regulação do modo de apropriação da riqueza pelo ser humano. Reconstituindo a história do conceito, Paolo Grossi, em estudo conhecido, observa que o modo mais apropriado de identificar-se a propriedade é defini-la como espécie de mentalidade jurídica ${ }^{1}$, tomada esta como um conjunto de valores enraizados em certo

* Doutorando e Mestre em Direito (UFRGS). Especialista em. Direito Internacional e em Direito Civil (UFRGS). Coordenador Acadêmico do Curso de Pós-Graduação em Direito do Consumidor da UFRGS; Professor dos Cursos de Pós-Graduação em Direito Internacional e de Regulação dos Serviços Públicos da UFRGS. Professor de Direito Civil da UNIRITTER e da Faculdade São Judas Tadeu.

1 Mentalidade jurídica, no caso, como "aquel conjunto de valores que circulan em uma área espacial y temporal, capaz por su vitalidad de separar la diáspora de los bechos y episódios aislados y de constituir el tejido conjuntivo escondido y constante de aquella área". Prossegue, então, referindo que "com visual fundamentalmente sincrônica ya que los valores tienden a permear la globalidad de la experiência, com procedimiento fundamentalmente sistemático ya que los valores tienden a permanecer y a cristalizarse, el jurista se siente a su comodidad - casí, se diria, em la propia casa - en el terreno de las mentalidades; es ahi donde lo jurídico tiene su raiz." GROSSI, Paolo. La propriedad y las propriedades. Um análisis bistórico. Trad. Angel Lopez y Lopez. Madrid: Cuadernos Civitas, 1992, p. 58. 
âmbito espacial e cultural, e que em cada etapa da histórica respeita um perfil específico. No caso, traça o professor italiano um paralelo entre as diferentes concepções sobre a propriedade no direito medieval e moderno ${ }^{2}$, cujos elementos de sentido, profundamente influenciados pela filosofia liberal de fins do século XVIII ${ }^{3}$, desembarcam na célebre definição legal do Code civil napoleônico, em seu artigo 544, indicando a propriedade como o direito que o seu titular exerce de la manière la plus absolute. Daí é que surge a identificação decisiva entre propriedade e sujeito: "uma modelação tão estrita como para parecer quase uma identificação: a propriedade é somente o sujeito em ação, o sujeito na conquista do mundo. Idealmente, as barreiras entre eu e men caem"'4. A célebre definição legal do Code, por certo, não é apenas a realização de um projeto ideológico da burguesia que ascendera ao poder na França pósrevolucionária, mas também o resultado do amadurecimento de uma certa compreensão individualista da identidade e disciplina dos direitos subjetivos em geral ${ }^{5}$.

Daí surge o clássico conceito, demonstrado entre nós por Pontes de Miranda, segundo o qual a propriedade engloba um feixe de poderes jurídicos, a partir do qual o proprietário pode a princípio, "utilizar a coisa, ou destruí-la, gravá-la ou praticar outros atos de disposição". Ou seja, trata-se de direito exclusivo e excludente, cujas prerrogativas são reconhecidas ao titular do direito, com a conseqüente exclusão de todos os demais, aos quais incumbe o mero dever de pacere (suportar). Neste sentido, integram o pólo passivo da relação jurídica de propriedade, identificando-se todos que não o titular do direito como sujeitos passivos; todos titulares do dever de abstenção oponível erga omnes pelo proprietário.

Esta noção de propriedade, como é sabido, altera-se substancialmente em meados do século XX, influenciada por novas tendências cuja marca será o reconhecimento da necessidade de se considerat, na concepção e exercício dos diversos poderes jurídicos vinculados à propriedade e a cutros direitos subjetivos, uma dimensão de socialidade ${ }^{7}$. Assim é que em rápida síntese - se passa a reconhecer em relação à propriedade o direito do seu titular exercer as prerrogativas que the são inerentes até onde tal exercício não ofenda o direito de outrem. E neste caso, para limitação dos limites do exercício - como bem afirma Pontes de

${ }^{2}$ Idem, p. 67 et seq.

${ }^{3}$ Franz Wieacker, dentre outros historiadores do direito, consigna a renovação da ciência jurídica operada pela filosofia idealista, a partir da ética de autonomia de Kant, a qual oferece ao direito privado um esquema lógico que permite vislumbrar como sistemas de esferas de liberdade da personalidade autônoma, em razão da qual uma das conseqüências será o reconhecimento da prerrogativa de livre uso da propriedade. WIEACKER, Franz. História do direito privado moderno. $2^{a}$ ed. Trad. Botelho Espanha. Lisboa, Calouste: Gulbenkian, 1993, p. 717.

${ }^{4}$ WIEACKER, op. cit., p. 130.

${ }^{5}$ Neste sentido, o entendimento de Stefano Rodotá. El terrible derecho. Estúdio sobre la propriedad privada. Trad. Luis Díez-Picazo. Madrid: Civitas, 1986, p. 102.

${ }^{6}$ PONTES DE MIRANDA, Francisco Cavalcante. Tratado de direito privado, t. 10. $4^{\mathrm{a}}$ ed. São Paulo: RT, 1977, p. 10-11.

7 Sobre o tema, veja-se a célebre conferência de Otto Gierke: GIERKE, Otto Von. La función social del derecho privado. Trad. Por José M. Navarro de Palencia. Madrid: Sociedade Española, 1904. 
Miranda - não se estará a indagar de malícia ou má-fé do proprietário para indicar tal exercício como irregular, mas sim da existência de uma irregularidade objetiva".

Atualmente o direito de propriedade passa a caracterizar-se como espécie de poderfunção, uma vez que, desde o plano constitucional, encontra-se diretamente vinculado à exigência de atendimento da sua função social ${ }^{9}$. Neste sentido, a posição de titular da propriedade impõe, ao lado das prerrogativas que lhe são inerentes, o cumprimento de deveres vinculados a outros bens jurídicos igualmente tutelados. Dentre estes estão os deveres jurídicos decorrentes do direito fundamental de preservação do meio ambiente, previsto no artigo 225 da Constituição $0^{10}$.

Esse trabalho não tem por finalidade avançar indistintamente sobre todos os condicionamentos da propriedade, estabelecidos ou não pela Constituição. Concentra-se, por outro lado, no exame da definição da propriedade no novo Código Civil e sua interpretação em razão do dever geral de preservação do meio ambiente consagrado no direito brasileiro a partir da Constituição. Seus objetivos, assim, cingem-se em duas direções: primeiro, a identificação do dever geral de proteção do meio ambiente como espécie de condicionamento do direito de propriedade e de sua função social; e segundo, o exame destes deveres e sua conformação na legislação ordinária.

\section{O NOVO CÓdIGO CIVIL E A DEFINIÇÃO JURÍdICA DE PROPRIEDADE}

No século XIX, propunha Lafayette Rodrigues Pereira, duas definições de propriedade ${ }^{11}$. Uma em sentido genérico, abrangendo todos os direitos que formam o patrimônio do indivíduo, e que portanto, podem ser reduzidos a valor pecuniário; e outro restrito, compreendendo apenas o direito que tem por objeto direto e imediato as coisas corpóreas, assinalando que a esta concepção restrita, denomina-se igualmente domínio. Ao domínio, de sua vez indicava o jurista em seu Direito das cousas, três atributos essenciais: "1. que o domínio envolve a faculdade de gozar de todas as vantagens e utilidades que a cousa encerra, sob quaesquer relaçôes; 2. que é illimitado, e como tal inclue em si o direito de

\footnotetext{
${ }^{8}$ PONTES DE MIRANDA. Tratado..., p. 27.

${ }^{2}$ Neste sentido, veja-se, dentre outros: RIOS, Roger Raupp. Funçâo social da propriedade. Lex. Jurisprudência do STJ e dos Tribunais Regionais Federais, ano 6, n 55. São Paulo: Lex Editora, março/1994, p. 17-27.Da mesma forma, para função social da propriedade como princípio da ordem constitucional econômica, veja-se: PET"TER, Lafayete Josué. Princípios constitucionais da ordem econômica. O significado e o alcance do art. 170 da Constituição Federal. São Paulo: RT, 2005, p. 208 et seq.

${ }^{10}$ Art. 225. Todos têm direito ao meio ambiente ecologicamente equilibrado, bem de uso comum do povo e essencial à sadia qualidade de vida, impondo-se ao Poder Público e à coletividade o dever de defendê-lo e preservá- lo para as presentes e futuras gerações.

${ }^{11}$ PEREIRA, Lafayette Rodrigues. Direito das cousas. $2^{\mathrm{a}}$ ed. Rio de Janeiro: Jacintho Ribeiro dos Santos, s.d., p. 63-64.
} 
praticar sobre a cousa todos os actos que são compativeis com as leis da natureza"; 3. que é de sua essencia exclusivo, isto é, contém em si o direito de excluir da cousa a acção de pessoas estranbas"12.

Legalmente, contudo, a definição jurídica de propriedade, fez-se entre nós em razão, essencialmente, dos poderes inerentes a ela a partir do titular destes, o proprietário ${ }^{13}$. Deste modo, está previsto no artigo 524 do Código Civil de 1916: "a lei assegura ao proprietário o direito de usar, gozar e dispor de seus bens, e de reavê-los do poder de quem quer que injustamente os possua. ${ }^{\prime \prime 4}$ A definição jurídica de propriedade, assim, em nosso direito, completava-se pela precisão de sua plenitude (artigo $525^{15}$ ), em relação a qual se estabelecia presunção em favor do proprietário (artigo $527^{16}$ ), ao mesmo tempo que determinava-se a extensão do objeto da relação jurídica proprietária de bens imóveis na medida da sua utilidade (artigo $526^{17}$ ).

A definição clássica de propriedade fez-se, portanto, em destaque dos poderes que lhe são inerentes e suas características de plenitude exclusividade. Contudo, desde algum tempo, tal concepção da propriedade - conforme assinalamos - deixou de ser vislumbrado em termos absolutos, próprio de suas origens. Seguiram-se nesta direção os estudos de fins do século XIX e início do século XX, que a partir do direito subjetivo de propriedade reconheceram em toda a categoria dos direitos subjetivos a necessidade de imposição de limites jurídicos, cuja violação dissocia a existência do direito (com a proteção que o ordenamento jurídico lhe confere), e o exercício deste mesmo direito, o qual poderia sim qualificar-se como abusivo e neste sentido, ilícito. A teoria do abuso do direito ${ }^{18}$, desde seus

12 Idem, p. 64-65.

${ }^{13}$ Não era esta, entretanto, a opção e Teixeira de Freitas no seu Esboço do Código Civil. Propunha o jurista, no artigo 4071, uma definição de domínio, nos seguintes termos: "Art. 4.071 - Dominio (direito de propriedade sobre coisas) é o direito real, perpétuo ou temporário, de uma só pessoa sobre coisa própria, móvel ou imóvel, com todos os direitos sobre sua substância e utilidade, ou somente sobre sua substÂncia, ou somente sobre sua substância e alguns sobre sua utilidade." TEIXEIRA DE FREITAS, Augusto. Esboço do Código Civil, v. 2. Brasília: Ministério da Justiça, 1983, p. 575

${ }^{14}$ Como assinala Clóvis Beviláqua, esta opção legislativa, sem prejuízo de outras definições, embasava-se na regra romana de domínio: "domminium est jus utendi, fruendi et abutendi re sua, quatenus juris ratio patitur”. BEVILÁQUA, Clóvis. Direito das coisas, v.1. Rio de Janeiro: Freitas Bastos, 1941, p. 133-134.

15 Art. 525. É plena a propriedade, quando todos os seus direitos elementares se acham reunidos no do proprietário; limitada, quando tem ônus real, ou é resolúvel.

${ }^{16}$ Art. 527. O domínio presume-se exclusivo e ilimitado, até prova em contrário.

${ }^{17}$ Art. 526. A propriedade do solo abrange a do que the está superior e inferior em toda a altura e em toda a profundidade, úteis ao seu exercício, não podendo, todavia, o proprietário opor-se a trabalhos que sejam empreendidos a uma altura ou profundidade tais, que não tenha ele interesse algum em impedi-los.

${ }^{18}$ Sobre o tema veja-se o clássico: JOSSERAND, Louis. De l'espirit des droits et de leur relativité: théorie dite l'abus des droits. Paris: [s.n.], 1927, p. 322 er seq. No direito brasileiro, veja-se por todos: MARTINS, Pedro Baptista.$O$ abuso do direito e o ato ilícito. 3 ed. histórica com considerações preliminares à guisa de atualização de José da Silva Pacheco. Rio de Janeiro: Forense, 1997, p. 81-118. 
primórdios, ainda que seja insistentemente vinculada por muitos autores ${ }^{19}$ até hoje $\mathrm{e}^{20}$ como tendo uma mattiz subjetiva (de rejeição dos atos meramente emulativos), na verdade desenvolve internamente no direito civil a primeira tese organizada que reconhece a possibilidade de imposição de limites ao exercício dos direitos subjetivos de natureza social, permitindo assim identificar no mau exercício, ou no exercício que descuida da finalidade social e econômica do instituto da propriedade, um ato a ser coibido e, portanto, sancionado pela ordem jurídica ${ }^{21}$.

\subsection{A propriedade como fonte de deveres jurídicos}

É certo que nada se equivale em importância para a alteração substantiva da noção clássica de propriedade em sua matriz jusracionalista, do que o tratamento que lhe vão oferecer os artigos $27, \$ 3^{\circ}$ da Constituição Mexicana, de 1917 , e $153, \$ 3^{\circ}$, da Constituição de Weimar, da Alemanha, de 1919. A norma mexicana vai consagrar, dentre outros condicionamentos aos direitos do proprietário, que "a Nação terá em todo o tempo o direito

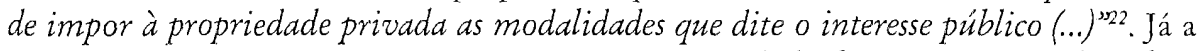
norma constitucional alemã, de sua vez, indica: "a propriedade obriga. Seu uso também deve servir ao bem da comunidade ${ }^{323}$.

19 A vinculação da teoria do abuso do direito com sua origem subjetiva, derivada dos atos emulativos (aemulatio) do direito medieval, tem sentido apenas se realizada com vistas aos célebres casos da jurisprudência francesa de fins da segunda metade do século XIX, e que serviram de objetos da reflexão doutrinária posterior. Esta fase pioneira, diga-se, desenvolveu-se sobretudo, com casos que reclamavam a limitação do direito de propriedade, como são exemplos os casos Lingard, Mercy e Lacante, relativos a fumos e maus cheiros de fábricas, e o caso Grosheintz, que girou sobre escavações no terreno do próprio titular que provocaram o desmoronamentodo terreno vizinho. Ainda o caso Doerr, dizendo respeito à construção de uma chaminé em terreno próprio com o fito exclusivo de retirat a luz do terreno vizinho; o caso Savart, em que o proprietário de um terreno construira uma estrutura de madeira com dez metros de altura, pintada de negro, com o objetivo de sombrear e entristecer o terreno vizinho; e, talvez o mais citado dos casos, o caso Clément-Bayard, em que o proprietário construiu em seu terreno um dispositivo de espigões de ferto com o objetivo de destruir os aerostatos do proprietário vizinho. Contudo, em sua elaboração doutrinária seguinte, desde logo reconhecerá a possibilidade de limites objetivos ao exercício de direitos subjetivos, como será o caso da finalidade econômica e social de um direito. Neste sentido veja-se: CUNHA DE SÁ, Fernando Augusto. Abuso do direito. Coimbra: Almedina, 1997, p 53 et seq.

${ }^{20}$ Neste sentido, a interpretação do artigo 187 do Código Civil vigente, feita pelo professor Humberto Teodoro Júnior, em seus Comentários publicados pela editora Forense: THEODORO JÚNIOR, Humberto. Comentários ao novo Código Civil: parte geral. 2i ed. Rio de Janeiro: Forense, 2002, v. 3, t. 2, p. 28.

${ }^{21}$ Neste sentido o excelente estudo de Maria Amália Dias de Moraes. Do abuso de direito: alguns aspectos. Revista da Procuradoria Geral do Estado do Rio Grande do Sul, Porto Alegre, v. 15, n.42, p. 11-26, 1985.

${ }^{22}$ Traduzi da transcrição de: CARROZZA, Antonio; ZELEDÓN, Ricardo Zeledón. Teoria general e institutos de derecho agrário. Buenos Aires: Editorial Astrea, 1990, p. 19.

${ }^{23}$ Assim a íntegra do artigo 153 da Constituição de Weimar: "A propriedade será garantida pela Constituição. Seu conteúdo e seus limites se deduzirão das leis. Somente se poderá expropriar em favor da comunidade e com fundamerito de direito, tendo sempre como contrapartida a correspondente inderização, exceto quando 
Duas as razões principais do profundo impacto destas normas no modo de conceberse a propriedade em direito privado. Primeiro, o fato de adotar-se a previsão de um instituto típico do direito privado na Constituição, norma de direito público. A segunda, visível com nitidez sobretudo na regra alemã - reproduzida em 1949 no artigo 14 da Lei Fundamental de Bonn - é exatamente que a propriedade, antes vista como fonte exclusiva de poderes jurídicos (jus utendi, fruendi e abutendi), passa a ser vislumbrada igualmente como fonte de deveres jurídicos do seu titular em relação à comunidade.

A evolução posterior do conceito é conhecida. Entre nós, a partir da Constituição de 1934 inicia-se a modificação substancial do conceito de propriedade em relação aos contornos originários do direito civil clássico. Em seus artigos 113 e 118, estabeleceu como propriedades distintas do solo as minas e as quebras d'água para fins de exploração ou aproveitamento industrial e, sobretudo, determinou que o direito de propriedade não poderia ser exercido contra o interesse social ou coletivo ${ }^{24}$. A transformação da noção de propriedade em direito brasileiro ${ }^{25}$ veio a se consolidar, contudo, a partir da Constituição de 1946, quando esta estabeleceu que uso da propriedade deve estar condicionado ao bem-estar social, assim como fez uma primeira referência a que se realize a justa distribuição da propriedade, com igual oportunidade para todos (artigos 141, \$16, e 147). A expressão função social da propriedade, de sua vez, restou consagrada em nosso sistema apenas com a Constituição de 1967, na qualidade de princípio informador da ordem econômica (artigo 157, III).

Na Constituição vigente, de 1988, o constituinte indicou à função social da propriedade um lugar de destaque na morfologia constitucional. A rigor, a previsão normativa da função social determina-lhe duas diferentes qualidades: trata-se ao mesmo tempo de um dever jurídico oponível ao titular do direito de propriedade (artigo $5^{\circ}$, inciso XXIII) e de princípio informador da ordem econômica (artigo 170, inciso III), nos termos do que jă havia sido consagrado pela ordem constitucional anterior. Ao mesmo tempo o texto constitucional

uma lei do Reich determine outra coisa. Com relação à quantia da indenização, se manterá aberta no caso de litígio a via dos tribunais competentes, exceto quando uma lei do Reich determine o contrário. As expropriações feitas pelo Reich, Länder, municípios e associações de uso público só poderão efetuar-se mediante indenização. A propriedade obriga Seu uso também deve servir ao bem da comunidade." Traduzi de HATTENHAUER, Hans. Conceptos fundamentales del derecho civil. Introducción bistóricodogmática. Trad. Gonzalo Hernandez. Barcelona: Ariel, 1987, p. 123.

${ }^{24}$ Clóvis Beviláqua, ainda que identifique nas disposições constitucionais sobre propriedade, a partir da Constituição de 1934, uma inspiração socialista, admite que se tais não mais permitirão que seja compreendida como direito absoluto e ilimitado. BEVIL.ÁQUA. Direito das coisas, v. 1, p. 136.

${ }^{25}$ Note-se, de outro modo, que tanto na Constituição do Império, de 1824 , quanto na Constituição Republicana, de 1899, a referência á propriedade fez-se em sua concepção clássica, como direito pleno. Assim, o artigo 179 da Constituição de 1824: "É garantido o Direito de Propriedade em toda a sua plenitude". E o artigo $72, \$ 17$, da Constituição de 1899: "O direito de propriedade mantém-se em toda a sua plenitude...As minas pertencem aos proprietários do solo, salvas as limitações que forem estabelecidas por lei a bem da exploração deste ramo de indústria" 
distingue, no que se refere ao atendimento desta função social, quanto ao fato de tratar-se de propriedade urbana ou rural. No primeiro caso, remete-se a aferição do atendimento da função social às exigências fundamentais de ordenação da cidade expressas no plano diretor (artigo 182, $\$ 2^{\circ}$ ). Em relação à propriedade rural, o artigo $186 \mathrm{da}$ Constituição estabelece quatro critérios ${ }^{26}$ para aferição do cumprimento do preceito.

A pergunta do que seja propriedade, ou seja, a definição jurídica de propriedade no direito brasileiro hoje, não prescinde da exata determinação das coordenadas constitucionais acerca do tema. Seja no que se refere à sua função social - conforme já referimos - ou mesmo em relação às limitações estabelecidas em razão do interesse público previstas na Constituição ou na legislação infraconstitucional que lhe conforma.

Em primeiro lugar, passa-se a considerar não mais a existência de conceito uno e abstrato de propriedade, subordinado a um regime jurídico geral ${ }^{27}$, passando-se a admitir sua diversificação em novas e diferentes formas de apropriação de bens ${ }^{28}$.

Para alguns autores, todavia, a função social prevista pela Constituição para a propriedade privada e o reconhecimento do direito de propriedade como direito humanocom sua correspondente função de proteção da pessoa - determina a conseqüência que "nem toda a propriedade há de ser considerada direito fundamental, e como tal protegida" ${ }^{29}$. $\mathrm{O}$ desenvolvimento deste raciocínio leva à distinção entre diferentes espécies de propriedade, sendo algumas merecedoras de um tratamento especial do direito positivo (no caso das próprias normas constitucionais que protegem a pequena e média propriedade rural ${ }^{30}$ ), e outras com definição aplicável apenas ao direito ordinário.

Em conseqüuencia, no que se refere à propriedade reconhecida como direito fundamental e a função social assegurada em mesmo nível pela Constituição, sua consideração implica no reconhecimento de deveres fundamentais que lhe são correspectivos (ius et obligatio correlata sunt). Estes deveres de sua vez teriam sua determinação reconhecida ao legislador ordinário (artigos 182, $\$ 2^{\circ}$ e $\left.187 \mathrm{da} \mathrm{CR} / 88\right)^{31}$, que estritamente vinculado aos preceitos constitucionais, deverá estabelecer que o fato do descumprimento da função social da propriedade retira do proprietário as garantias de proteção judicial e extrajudicial inerentes

${ }^{26}$ São eles: "I - aproveitamento racional e adequado; II " utilização adequada dos recursos naturais disponiveis e preservação do meio ambiente; III - observância das disposições que regulam as relações de trabalbo; IV - exploração que favoreça o bem-estar dos proprietários e dos trabalhadores."

${ }^{27}$ Neste sentido veja-se: TEPEDINO, Gustavo. Contornos constitucionais da propriedade privada. Temas de direito civil. Rio de Janeiro: Renovar, 1999, p. 278-279.

${ }_{2 B}^{2 B}$ RODOTÁ. El terrible derecho..., p. 253

29. Neste sentido o entendimento de Fábio Konder Comparatto. Direitos e deveres fundamentais em matéria de propriedade. Revista de Centro de Estudos Judiciários. Brasilia: Conselho da Justiça Federal, dezembro/1997, p. 92-99.

30) Assim os artigos $5^{\circ}$, inciso XXVI, e 185 da Constituição de 1988.

31 COMPARATTO. Direitos e deveres fundamentais..., p. 96. 
a este direito, como por exemplo os instrumentos de proteção possessória, e o direito a prévia e justa indenização ${ }^{32}$.

Não se desconhece que ao elevar a propriedade a categoria constitucional vinculou-se a mesma de modo definitivo ao cumprimento da função social, terminando por diminuir em certo grau, o nível de garantia/proteção indicado ao direito, em face da sua própria relativização ${ }^{33}$. Da mesma forma, funcionalização do direito significa sua vinculação a objetivos projetados, o que certamente impõe ao titular da propriedade deveres inerentes à realização dos mesmos.

Contudo, não se deve chegar ao limite de condicionar sua proteção jurídica em relação a terceiros, ao cumprimento da função social. Inclusive pelo fato de que nessa proteção incluem-se prerrogativas de outra natureza, independentes da existência do direito de propriedade, como é o caso da posse $e^{34}$.

A rigor, a função social da propriedade relacionada no catálogo de direitos fundamentais tem como primeira conseqüência a vinculação, desde o ápice da pirâmide normativa, da correlação entre o direito subjetivo de propriedade e o dever jurídico oponível ao seu exercício, de cumprimento a respectiva finalidade social. Trata-se, assim, de uma espécie de poder-função ${ }^{35}$ ou poder-dever ${ }^{36}$, cujos condicionamentos específicos serão estabelecidos pelo legislador a partir das coordenadas constitucionais, como é o caso das obrigações relativas ao uso racionale adequado da propriedade rural, na ordenação da ocupação do espaço urbano, ou as pertinentes à utilização adequada dos recursos naturais disponíveis e preservação do meio ambiente.

32 Acetca da desapropriação por interesse social, refere Comparatto: "Ela constitui na verdade a imposição administrativa de uma sanção, pelo descumprimento do dever, qye incumbe a todo o proprietátio, de dar certos e determinados bens uma destinação social. Por isso mesmo, é antijurídico atribuir ao expropriado, em tal caso, uma indenização completa, correspondente ao valor venal do bem rnais compensatórios, como se não tivesse havido abuso do direito de propriedade." Idem, p. 97.

${ }^{33}$ Neste sentido: RODOTÁ. El terrible derecho..., op.cit., p. 324 e 375.

${ }^{34} \mathrm{O}$ artigo 485 do Código Civil anterior, reproduzido no artigo 1196 do Código vigente "Considera-se possuidor todo aquele que tem de fato o exercício, pleno ou não, de algum dos poderes inerentes à propriedade"), estabelece que a basta para a posse o poder de fato sobre a coisa, a relação de pertinência fática entre o sujeito e o corpus, quando se vai afirmar no direito brasileiro que este poder representase por intermédio do exercício fático de uma das prerrogativas do domínio (ius utendi, fruendi ou abutendi). Neste sentido, resta consagrado para a maioria da doutrina de que nosso direito adota a teoria objetivista da posse, elaborada por Ihering na pandectística alemão do século XIX, em contraposição à teoria subjetivista de Savigny, a exigir para configuração da relação possessória, o corpus e o animus. Vejase o exame de Pontes de Miranda sobre as teorias da posse: Tratado de direito privado, t. X.

${ }^{35}$ Assim o entendimento, dentre outros de: GOMES, Otlando. Novas dimensões da propriedade privada. Revista dos Tribunais, n 411. São Paulo: RT, janeiro/1970, p. 12; RIOS, Roger Raupp. Função social da propriedade, op. cit., p. 19. Da mesma forma posiciona-se André Godinho, o qual busca salientar que a função social não significa uma negação do direito subjetivo, mas que "é a função social razão de tutela $e$ garantia da propriedade privada". GODINHO, André Osório. Função social da propriedade. In: TEPEDINO, Gustavo (Coord.) Problemas de direito civil constitucional. Rio de Janeiro: Renovat, 2000, p. 1-16.

${ }^{36}$ COMPARATO, Fábio Konder. Função social da propriedade dos bens de produção. Revista de Direito Mercantil, Industrial, Econômico e Financeiro (nova série). São Paulo, RT, n. ${ }^{\circ}$ 63, jul-set/1986, p. 76. 


\subsection{A propriedade como fonte de deveres jurídicos em matéria de preservação do meio ambiente}

O novo Código Civil, ao consagrar o direito de propriedade, o faz em termos mais amplos do que o de 1916. Neste sentido, ao mesmo tempo em que seu artigo 1228, caput, tenha praticamente reproduzido o artigo do Código anterior, apenas com o acréscimo de referência expressa à possibilidade de reivindicação pelo proprietário também na hipótese de detençã ${ }^{37}$, incluiu na mesma disposição conceitual elementos que induzem para uma nova definição de propriedade dentro do direito civil.

O artigo 1228 do Código Civil, ao tratar de definir a propriedade, o faz de modo coordenado com uma série de outros interesses juridicamente protegidos pela Constituição. É este o caso da tutela dirigida à posse coletiva e a possibilidade de desapropriação judicial para fins de regularização fundiária $\left(\$ \subseteq 4^{\circ} \text { e } 5^{\circ}\right)^{38}$, ou a previsão acerca da desapropriação por necessidade ou utilidade pública, ou interesse social $\left(\$ 3^{\circ}\right)^{39}$. E não se trata apenas de a interpretação da norma de direito civil dar-se em acordo com as disposições constitucionais ${ }^{40}$, senão que estas tem o objetivo de conformar ${ }^{41}$, para aplicação às situações concretas, as normas assecuratórias de direitos ou posições jurídicas estabelecidas na Constituição ${ }^{42}$.

No que interessa a esse estudo, contudo, de maior interesse é o $\$ 1^{\circ}$ do artigo 1228 do Código Civil. Refere esta norma que: "O direito de propriedade deve ser exercido em consonância com as suas finalidades econômicas e sociais e de modo que sejam preservados, de conformidade com o estabelecido em lei especial, a flora, a fauna, as belezas naturais, o equilibrio ecológico e o patrimônio bistórico e artístico, bem como evitada a poluição do ar e das águas."

${ }^{37}$ Art. 1.228. O proprietário tem a faculdade de usar, gozar e dispor da coisa, e o direito de reavề-la do poder de quem quer que injustamente a possua ou detenha (...).

38 " $54^{2} \mathrm{O}$ proprietário também pode ser privado da coisa se o imóvel reivindicado consistir em extensa área, na posse ininterrupta e de boa-fé, por mais de cinco anos, de considerável número de pessoas, e estas nela houverem realizado, em conjunto ou separadamente, obras e serviços considerados pelo juiz de interesse social e econôtmico relevante. $₫ 5^{\circ}$ No caso do parágrafo antecedente, o juiz fixará a justa indenização devida ao proprietário; pago o preço, valerá a sentença como título para o registro do imóvel em nome dos possuidores."

39 " $3^{2}$ O proprietário pode ser privado da coisa, nos casos de desapropriação, por necessidade ou utilidade pública ou interesse social, bem como no de requisição, em caso de perigo público iminente."

${ }^{40}$ No caso, o emprego da técnica da interpretação conforme à Constituição para determinação do significado das normas de direito ordinário do Código Civil de modo compatível com as normas constitucionais. Neste sentido, veja-se: COELHO, Inocêncio Mártires. O novo Código Civil e a interpretação conforme a Constituição. In: FRANCIULLI NETO, Domingos. MENDES, Gilmar Ferreira. MARTINS FILHO, Ives Gandra (Coord.) O novo Código Civil. Estudos em bomenagem ao Prof. Miguel Reale. São Paulo: LTr, p. 25-53.

4i Neste sentido, veja-se a lição de Canotilho acerca das normas restritivas e conformadoras de direitos fundamentais: CANOTILHO, J. J. Gomes. Direito constitucional e teoria da Constituição. $3^{\mathrm{a}}$ ed. Coimbra: Almedina, 1998, p. 647.

${ }^{42}$ Acerca desta nova postura do legislador ordinário frente a Constituição, veja-se: TEPEDINO, Gustavo. O Código Civil, os chamados microssistemas e a Constituição: premissas para uma reforma legislativa. In: Problemas de direito civil constitucional..., p. 1-16. 
Discorrendo sobre a propriedade, refere Pontes de Miranda que "todo o direito subjetivo é linha que se lança em certa direção. Até onde pode ir, ou até onde não pode ir, previsto pela lei, o seu conteúdo ou seu exercício, dizem-no as regras limitativas, que são regras que configuram, que traçam a estrutura dos direitos e de sua exercitação. O conteúdo destas regras são as limitações" ${ }^{43}$.

No caso, o $\$ 1^{\circ}$ do artigo 1228 , do Código Civil, ao dispor sobre o exercício do direito de propriedade, incorpora, em termos legislativos, o que já reconhecia a doutrina, ou mesmo a legislação especial em matéria de preservação ambiental, de que o exercício da propriedade não pode se dar de modo lesivo/nocivo ao meio ambiente. Isto não se confunde com as limitações ou condicionamentos da propriedade com natureza administrativa (como o tombamento, desapropriação) $)^{44}$, ainda que com eles se relacione. Mas trata-se na verdade de elementos internos da própria definição do direito de propriedade.

Antônio Herman Benjamin, ao discutir os limites do direito de propriedade em artigo escrito antes da vigência do Código Civil de 2002, distingue seus limites em duas espécies: limites internos e externos, ambos expressando o desejo do legislador de, ora resguardar o indivíduo isoladamente considerado, ora com o intuito de alcançar objetivos supraindividuais. Os limites internos seriam aqueles conceituais típicos do direito de propriedade, como é o caso dos direitos dos outros proprietários, dos direitos de vizinhança, de proteção da saúde pública e o resguardo dos bons costumes. Os limites externos seriam decorrência das exigência de convivência em sociedade, refletindo preocupações mais complexas e difusas, tendo por origem comum a função social da propriedade ${ }^{45}$.

Com o advento do artigo 1228 do novo Código Civil e, em especial de seu $₫ 1^{\circ}$, esta distinção parece petder espaço. A primeira conseqüência desta nova definição legal é a eliminação de uma série de aparentes conflitos entre o direito de propriedade e o direito ao meio ambiente, porquanto aquele passa a ser reconhecido, em termos conceituais, apenas nas hipóteses em que é exercido de modo a respeitar integralmente este. Daí é que uma segunda questão aparece, como exigência de uma interpretação adequada - compatível com a Constituição - deste novo conceito de propriedade: objetivamente, no que consistiriam os deveres de preservação do meio ambiente referidos no $\$ 1^{\circ}$ do artigo 1228 ?

Em termos de imposição de deveres e aferição do seu cumprimento por aqueles a quem são endereçados, não é possível ficar adstrito aos termos do $₫ 1^{\circ}$ do artigo 1228 . Inclusive porque o controle eficiente do cumprimento destes deveres depende da sua razoável precisão em termos normativos.

43 PONTES DE MIRANDA, Tratado..., t. 10, p. 18.

${ }^{44}$ Ver-se por todos: FREITAS, Vladimir Passos. A Constituição Federal e a efetividade das normas ambientais. $2^{a}$ ed. rev. São Paulo: RT,2002, p. 133 et seq.

${ }^{45}$ BENJAMIN, Antônio Herman. Desapropriação, reserva legal, e áreas de preservação permanente. Revista do Centro de Estudos Judiciários, v. 1, n.3. Brasília: Conselho da Justiça Federal, setembrodezembro/1997, p. 33-41. 
Não está aqui uma crítica ao legislador. Ao contrário. Em termos conceituais o artigo 1228 estabeleceu uma norma até onde o Código Civil deve fazê-lo, ou seja, indicando a natureza dos poderes inerentes à propriedade, as disposições que realizam/conformam direitos ou posições jurídicas determinadas pela Constituição, e as pautas indicadas ao exercício do respectivo direito subjetivo. Em relação a estas últimas, contudo, o próprio $\$ 1^{\circ}$ do artigo 1228 remete à lei especial o estabelecimento dos deveres jurídicos relativos à preservação da flora e fauna, das belezas naturais, do equilíbrio ecológico e do patrimônio histórico e artístico, assim como para que seja evitada a poluição do ar e das águas.

Daí porque o detalhamento dos deveres jurídicos do proprietário em relação à preservação ambiental só pode ser realizado tendo em vista a legislação especial, ainda que no próprio Código Civil localizem-se disposições que, sob certas circunstâncias fáticas, tem sua aplicação vinculada à realização do meio ambiente - caso, por exemplo, dos artigos $1277^{46}$, $1291^{47}$, e $1309^{48}$. Estes deveres então, vão se apresentar tanto como deveres relativos à disposição dos bens móveis e imóveis de modo a não permitir lesão ao ambiente, quanto deveres vinculados às prerrogativas de uso e gozo dos bens. Em qualquer caso, poderá consistir tanto na abstenção de uma determinada atuação em que o exercício da propriedade possa gerar espécie de degradação ou dano ao meio ambiente, quanto em um comportamento positivo, pelo qual em face da titularidade do direito sobre a coisa, seja exigida do proprietário a realização de um dever positivo, um dever típico de prestação.

\section{DEFINIÇÃO LEGAL DE PROPRIEDADE E OS DEVERES DO PROPRIETÁRIO EM MATÉRIA PRESERVAÇÃO DO MEIO AMBIENTE}

A definição legal de propriedade no novo Código Civil, como vimos, condiciona expressamente a regularidade do exercício do direito ao cumprimento de deveres de preservação do meio ambiente. A definição destes deveres, de sua vez, foi indicada à legislação especial de proteção do meio ambiente, por expressa remessa da norma geral do Código.

A proteção do meio ambiente no direito brasileiro é assegurada em razão do direito fundamental estabelecido no artigo 225 da Constituição, que refere: "Todos têm direito ao

${ }^{46}$ Art, 1.277. O proprietário ou o possuidor de um prédio tem o direito de fazer cessar as interferências prejudiciais à segurança, ao sossego e à saúde dos que o habitam, provocadas pela utilização de propriedade vizinha. Parágrafo único. Proíbem-se as interferências considerando-se a natureza da utilização, a localização do prédio, atendidas as normas que distribuem as edificações em zonas, e os limites ordinários de tolerância dos moradores da vizinhança.

${ }^{47}$ Art. 1.291. O possuidor do imóvel superior não poderá poluir as águas indispensáveis às primeiras necessidades da vida dos possuidores dos imóveis inferiores; as demais, que poluir, deverá recuperar, ressarcindo os danos que estes sofrerem, se não for possível a recuperação ou o desvio do curso artificial das águas.

${ }^{48}$ Art. 1.309. São proibidas construções capazes de poluir, ou inutilizar, para uso ordinário, a água do poço, ou nascente alheia, a elas preexistentes. 
meio ambiente ecologicamente equilibrado, bem de uso comum do povo e essencial à sadia qualidade de vida, impondo-se ao Poder Público e à coletividade o dever de defendê-lo e preservá-lo para as presentes e futuras gerações". Para tanto, o $\$ 1^{\circ}$, do mesmo artigo $225^{49}$ remete ao legislador ordinário uma série de providências legislativas, como é o caso da proteção da flora e da fauna (inciso VII) e a exigência de estudo prévio de impacto ambiental, para instalação de obra ou atividade potencialmente lesivas ao meio ambiente (inciso IV).

O direito fundamental ao meio ambiente, neste sentido, pertence à categoria de direitos fundamentais que Robert Alexy denomina direitos a algo ${ }^{50}$, consistente em ações positivas e negativas Estado, de abster-se da realizar ações danosas ao meio ambiente (negativa); ou de realizar prestações de natureza fática ou normativa (positivas), visando sua promoção ou proteção ${ }^{51}$ do bem juridicamente protegido.

A prestação normativa do Estado, neste caso, além do estabelecimento das definições jurídicas dos bens protegidos, o fará igualmente em vista do estabelecimento dos deveres jurídicos exigiveis da comunidade para efetivação do direito constitucionalmente assegurado ${ }^{52}$. Neste particular, a interpretação do artigo $1228, \$ 1^{\circ}$ do Código Civil, no que diz respeito à precisão da definição jurídica de propriedade, guarda relação necessária com as definições estabelecidas na legislação ambiental.

Os conceitos adotados na norma de direito civil pertinentes à matéria ambiental são "a flora, a fauna, as belezas naturais, o equilíbrio ecológico e o patrimônio bistórico e artístico", assim como faz-se expressa referência ao mandamento de evitar "a poluiç̧ão do ar

49 " $\int 1^{\circ}$ - Para assegurar a efetividade desse direito, incumbe ao Poder Público: $I$ - preservar e restaurar os processos ecológicos essenciais e prover o manejo ecológico das espécies e ecossistemas; II - preservar a diversidade e a integridade do patrimônio genético do País e fiscalizar as entidades dedicadas à pesquisa e manipulação de material genético; III - definir, en todas as unidades da Federação, espaços territoriais e seus componentes a serem especialmente protegidos, sendo a alteração e a supressão permitidas somente através de lei, vedada qualquer utilização que comprometa a integridade dos atributos que justifiquem sua proteção; IV - exigir, na forma da lei, para instalação de obra ou atividade potencialmente causadora de significativa degradação do meio ambiente, estudo prévio de impacto ambiental, a que se dará publicidade; V - controlar a produção, a comercialização e o emprego de técnicas, métodos e substâncias que comportem risco para a vida, a qualidade de vida e o meio ambiente; VI - promover a educação ambiental em todos os níveis de ensino e a conscientização pública para a preservação do meio ambiente; VII - proteger a fauna e a flora, vedadas, na forma da lei, as práticas que coloquem em risco sua função ecológica, provoquem a extinção de espécies ou submetam os animais a crueldade."

${ }^{50}$ ALEXY, Robert. Teoria de los derechos fundamentales. Madrid: Centro de Estudios Políticos y Constititucionales, 2001, p. 196 et seq.

${ }^{51}$ ALEXY, Robert. Idem, p. 196. Para o exame desta qualidade no direito brasileiro, veja-se o recente estudo de Anízio Pires Gavião Filho. Direito fundamental ao ambiente. $1^{2}$ ed. Porto Alegre: Livraria do Advogado, 2005, p. 48 et seq.

${ }^{52}$ Anízio Gavião em seu estudo sobre o direito fundamental ao ambiente percebe com grande competência as dificuldades de determinação da conduta devida para o objetivo de realização do direito assegurado, assim como a necessidade de especificar/precisar os conceitos empregados. GAVIÃO FILHO. Idem, p. $160-163$. 
e das águas”. Desejou certamente o legislador civil ampliar o âmbito de proteção normativo, ao lançar mão de diversas expressões indicativas dos bens jurídicos a serem considerados no exercício da propriedade, com vistas a assegurar-se do respeito ao meio ambiente no tocante às relações jurídicas que the digam respeito.

\section{Equilíbrio ecológico}

Das expressões utilizadas, talvez a de equilíbrio ecológico seja a que maior significado tenha em termos de limitação do exercício do direito de propriedade. A própria Constituição adota o conceito de equilíbrio ecológico quando define o direito fundamental ao meio ambiente, adotando qualificação que - no exato entendimento de José Afonso da Silva não deve ser desprezada, uma vez que "apresenta valor teleológico mais aberto e mais amplo do que o sentido finalístico concreto" do que a opção de outros países, como é o caso da Constituição espanhola. Conclui, então, indicando que "o termo empresta sentido especial ao equilibrio ambiental, que não bá de ser estático, mas também não puramente natural ${ }^{353}$.

A concepção equilíbrio ecológico, assim, remete a uma exigência qualitativa, de que não é bastante para o respeito aos limites do exercício da propriedade a manutenção de qualquer equilíbrio, senão daquele em conformidade com os preceitos ecológicos. Tal qualificação remete à noção de coexistência saudável e apta a preservação da vida, entre os interesses do proprietário e a proteção dos bens submetidos a seu poder, bem como em relação aos interesses da comunidade, dado os reflexos da atuação do proprietário no exercício de suas prerrogativas juridicas.

\section{Fauna e flora}

A fauna e a flora, ainda que não se tenha uma definição legal específica, são tomadas em seu sentido comum, com o competente aporte científico, designando todos os seres vivos, animais e vegetais, em suas relações com o ambiente. Em relação à fauna - como anota Paulo Affonso Leme Machado - a Constituição estabelece três aspectos principais de sua proteção, quais sejam: a vedação de práticas que coloquem em risco sua função ecológica; práticas que possam provocar a extinção de espécies; e práticas que submetam os animais à crueldade ${ }^{54}$.

53 Prossegue então afirmando: "O ecologicamente refere-se, sim, também à harmonia das relações e interações dos elementos do habitat, mas deseja especialmente ressaltar as qualidades do meio ambiente mais favoráveis à qualidade da vida. Não ficará o homem privado de explorar os recursos ambientais, na medida em que isto também melhora a qualidade da vida humana; mas não pode ele, mediante tal exploração, desqualificar o meio ambiente de seus elementos essenciais, porque isso importaria desequilibrá-lo e, no futuro, implicaria seu esgotamento (...) o que a Constituição quer evitar, com o emprego da expressäo "meio ambiente ecologicamente equílibrado, é a idéia, possível, de um meio ambiente equilibrado sem qualificação ecológica, isto é, sem relações essenciais dos seres vivos entre si e deles com o meio". SILVA, José Afonso da. Direito ambiental constitucional. $5^{a}$ ed. São Paulo: Malheiros, 2004, p. 87-88.

${ }^{54}$ MACHADO, Paulo Affonso Leme. Direito ambiental brasileiro. $11^{\text {a }}$ ed. Säo Paulo: Malheiros, 2003, p. 126. 


\section{Patrimônio histórico e artístico}

O patrimônio histórico e artístico é determinada no direito brasileiro a partir das próprias normas constitucionais, como parte do patrimônio cultural do país. $\mathrm{O}$ artigo 216 da Constituição refere: "constituem patrimônio cultural brasileiro os bens de natureza material e imaterial, tomados individualmente ou em conjunto, portadores de referência à identidade, à ação, à memória dos diferentes grupos formadores da sociedade brasileira". Seu inciso V, então, vai incluir no patrimônio cultural "os conjuntos urbanos e sítios de valor histótico, paisagístico, artístico, arqueológico, paleontológico, ecológico e científico".

A qualificação de determinado conjunto de bens como dotados de valor próprio para integrarem o patrimônio cultural, e daí determinarem limitações ao exercício do direito de propriedade por seus titulares, respeitará a procedimento estabelecido em lei. O que no caso, por se encontrarem vinculados em nível constitucional à competência comum dos entes federados (proteção de paisagens naturais notáveis - artigo 23, inciso III), ou à competência legislativa concorrente, no que se refere à proteção do patrimônio paisagístico (artigo 24, VII), vai subordinar-se aos preceitos normativos editados nos três níveis da Federação.

\section{Belezas naturais}

Ínsita à determinação do significado de patrimônio bistórico e artístico previsto no artigo $1228, \$ 1^{\circ}$ do Código Civil, está a de belezas naturais, igualmente referida nesta mesma norma. Em nivel constitucional, a discussão aproxima-se da interpretação do conceito de patrimônio paisagístico, presente nos artigos 216, inciso V e 24, inciso VII da Constituição. Examinando a questão, a doutrina especializada ${ }^{55}$ refere que a noção de patrimônio é mais larga do que a de propriedade, projetando um relacionamento de gerações, na medida que as gerações presentes conservarão paisagens não apenas para si, mas para as que virão. Neste sentido, defende-se que tal concepção não serve para torná-la imobilizada, mas sim conferirlhe durabilidade, através de processos de desenvolvimento sustentado.

Então que se sugere-se a definição de paisagem como sendo "a relação que se estabelece entre um lugar e um momento concreto, entre um observador e o espaço que ele abrange com o olhar" ${ }^{\prime 56}$. Trata-se de uma relação entre sujeito e objeto, que não pode ser dissociada, sendo o objeto percebido pelo sujeito, que dele realiza uma descrição subjetiva ${ }^{57}$.

Uma interpretação jurídica da expressão beleza natural, como exige o artigo 1228, $\$ 1^{\circ}$ do Código Civil, reclama do intérprete o recurso a um raciocínio semelhante. Tal como se

\footnotetext{
${ }_{55}^{5}$ MACHADO, Paulo Affonso Leme. Direito ambiental brasileiro, p. 129.

${ }^{56}$ MORAND-DEVILLER, Jacqueline. Enviroment et paysage. Actualité Juridique - Droit Administratif, 20.9.1994. Apud: MACHADO, Paulo Afonso Leme. Direito ambiental brasileiro, p. 129

${ }^{57}$ MACHADO. Op. cit., p. 129.
} 
identifica com a paisagem, a noção de beleza natural ${ }^{58}$ é igualmente definição que pressupõe a relação entre o sujeito que percebe e a coisa percebida, de modo a se encontrar naquele o juízo valorativo de algo como belo ou bom. Neste caso, a formação do juízo sobre os elementos naturais não constituirá jamais uma decisão individual, mas sim um juízo comum, a partir da Constituição, segundo o qual os elementos do meio natural, existindo em equilíbrio ecológico, são percebidos naturalmente como belos e bons. Daí porque sua preservação (não-degradação) deverá orientar, no sentido da lei, o exercício do direito de propriedade por seu titular.

\section{Poluição do ar e das águas}

Em relação à poluição das águas e do ar, o $\$ 1^{\circ}$ do artigo 1228 determinou espécie de comportamento negativo, uma vez que indicou ao titular do direito um dever jurídico de evitar o fenômeno. Para determinação do conceito deve ser admitido, com fins de interpretação, a definição fixada em outras leis, como é o caso do artigo $3^{\circ}$, inciso III, da Lei Federal $n^{\circ} 6.938$, de 31 de agosto de 1981, que estabeleceu o Plano Nacional do Meio Ambiente - PNMA. Define esta norma, poluição como: "a degradação da qualidade ambiental resultante de atividade que direta ou indiretamente: a) prejudique a saúde, a segurança e o bem-estar da população; b) crie condições adversas às atividades sociais e econômicas; c) afete desfavoravelmente a biota; d) afete as condições estéticas ou sanitárias do meio ambiente; e) lance matérias ou energia em desacordo com os padrões ambientais estabelecidos."

Evidentemente que neste aspecto, ainda que esteja previsto no $\$ 1^{\circ}$ do artigo 1228 , do Código Civil, a proibição para a atividade poluente do ar e das águas, a interpretação desta norma deve se dar de modo extensivo, alcançando também os outros bens da vida integrantes do meio ambiente. Para tanto é extremamente útil o conceito de meio ambiente fixado na mesma Lei Federal $n^{\circ}$ 6938/81, que em seu artigo $3^{\circ}$, inciso I, indica-o como: "o conjunto de condições, leis, influências e interações de ordem física, química e biológica, que permite, abriga e rege a vida em todas as suas formas". Tanto para determinar ao $\$ 1^{\circ}$ a técnica de interpretação conforme a Constituição, quanto para indicar coetência interna com outros elementos da própria norma - como o equilíbrio ecológico - o $\$ 1^{\circ}$ do artigo 1228 , do Código Civil, não pode admitir outro significado que não seja a vedação expressa de toda a espécie de poluição, considerando-se pois, a degradação da qualidade ambiental em relação a qualquer bem da vida integrante do patrimônio ambiental.

\footnotetext{
${ }^{5 B}$ A filosofia até o século XVIII não fazia uma clara distinção entre a beleza natural e a beleza artística, uma vez que os artistas em geral concentravam-se, sobretudo, na reprodução/imitação da beleza natural.. Com a criação da estética como disciplina filosófica, no século XVIII, faz-se uma nítida distinção entre as duas espécies de beleza. Neste contexto, o próprio conceito de estética passa a ser cada vez mais reservado à apreciação das obras criadas peios homens, ainda que exclua totalmente as coisas da natureza.
} 


\subsection{Deveres do proprietário e legislação ambiental}

Resta ainda a definição dos deveres específicos do proprietário em matéria de preservação ambiental, o que por si só não pode ser retirado diretamente da Constituiçãa ${ }^{59}$ ou do Código Civil $^{60}$, mas sim das diversas normas especiais de proteção ambiental previstas no direito brasileiro. Da mesma forma, estes deveres não se apresentam homogêneos para todas as relações jurídicas de propriedade, dependendo da espécie de bens da vida subordinados ao direito subjetivo, e sua relevância para o meio ambiente.

E, ainda que se possam indicar muitas situações em que a relação jurídica de propriedade de bens móveis ou equiparados a tal apresenta relevância para a preservação do meio ambiente (assim, por exemplo, a propriedade de animais em geral, integrantes da fauna, ou mesmo de produtos poluentes ou perigosos) é no tocante à propriedade imobiliária que o ordenamento jurídico vai tratar de impor um maior número de condicionamentos, sobretudo por sua relevância para preservação do meio ambiente.

É este o caso das disposições previstas na Lei Federal n 9.985, de 19 de julho de 2000, que estabelece o Sistema Nacional das Unidades de Conservação. Tal diploma tem por finalidade, exatamente, o estabelecimento sobre certos territórios cuja extensão será determinada pelo Estado, de deveres jurídicos específicos imponíveis aos proprietários visando sua preservação ambiental ${ }^{61}$. Para tanto, institui as chamadas unidades de conservação, definidas como o "espaço territorial e seus recursos ambientais, incluindo as águas jurisdicionais, com características naturais relevantes, legalmente instituido pelo Poder Público, com objetivos de conservação e limites definidos, sob regime especial de administração, ao qual se aplicam garantias adequadas de proteção" (artigo $2^{\circ}$, inciso I).

Trata-se, no caso, de um regime jurídico específico determinado por ato do Poder Público, com o objetivo de impor condicionamentos especiais ao direito de propriedade sobre o bem, limitando assim os poderes de exploração do mesmo. Estabelecern-se, portanto, deveres de maior intensidade em relação aos comumente reconhecidos ao titular da propriedade, tendo em vista, sobretudo, as diretrizes do SNUC, previstas no artigo $5^{\circ}$ da Lei, e que compreendem, dentre outros, que: "no conjunto das unidades de conservação estejam representadas amostras significativas e ecologicamente viáveis das diferentes populações,

59 Ainda que em certos casos, mesmo remetendo a regulamentação da restrição para a lei ordinária, seja possível identificar na norma constitucional, o conteúdo do dever jurídico em questão. É o caso do artigo $225, \llbracket 2^{\circ}$, que estabelece, na forma da lei, em relação ao que explora recursos minerais, o dever de recuperar o meio ambiente degradado; assim como a restrição imposta à localização de usinas que operem com reator nuclear, decisão subordinada à Lei Federal (artigo 225, $\$ 6^{\circ}$ ).

60) Faço nova referência, todavia, aos artigos 1277, 1291 e 1309 do Código Civil.

${ }^{61}$ Acerca dos pressupostos técnicos destas limitações, veja-se o estudo de: BENSUSAN, Nurit. Os pressupostos biológicos do Sistema Nacional das Unidades de Conservação. In: BENJAMIN, Antônio Herman (Coord.) Direito ambiental das áreas protegidas. O regime jurídico das unidades de conservaşão. São Paulo: Forense Universitária, 2001, p. 164-189. 
habitats e ecossistemas do território nacional e das águas jurisdicionais, salvaguardando o patrimônio biológico existente (inciso I); assegurem, nos casos possíveis, a sustentabilidade econômica das unidades de conservação (inciso VI); permitam o uso das unidades de conservação para a conservação in situ de populações das variantes genéticas selvagens dos animais e plantas domesticados e recursos genéticos silvestres (inciso VII); busquem proteger grandes áreas por meio de um conjunto integrado de unidades de conservação de diferentes categorias, próximas ou contíguas, e suas respectivas zonas de amortecimento e corredores ecológicos, integrando as diferentes atividades de preservação da natureza, uso sustentável dos recursos naturais e restauração e recuperação dos ecossistemas (inciso XIII)".

As unidades de conservação, de sua vez, dividem-se em duas: as unidades de proteção integral $^{62}$ e as unidades de uso sustentável ${ }^{63}$. Nas primeiras, seu objetivo primordial é a preservação do meio ambiente, razão pela qual, quando admitido a exploração dos seus recursos naturais, esta deverá se dar de modo indireto (artigo $7^{\circ}, \$ 1^{\circ}$ ). Já em relação às unidades de uso sustentável, o objetivo principal será "compatibilizar a conservação da natureza com o uso sustentável de parcela dos seus recursos naturais" (artigo $7^{\circ}, \$ 2^{\circ}$ ).

Em ambos os casos, note-se que a razão de ser do instituto é a limitação do poder do proprietário individual em relação ao bem de sua propriedade, ou mesmo a extinção simples da propriedade pela desapropriação, com vistas à instituição das unidades de conservação.

No caso das unidades de proteção integral - à exceção do monumento natural e do refúgio da vida silvestre, em que se admite sua instituição em áreas particulares, "desde que seja possivel compatibilizar os objetivos da unidade com a utilização da terra e dos recursos naturais do local pelos proprietários" ${ }^{\text {(t+- }}$ - serão sempre instituídas em bens de domínio público. $\mathrm{E}$ mesmo no caso do monumento natural ou do refúgio da vida silvestre, na hipótese de não ser possível, ou não existir a concordância do proprietário em relação às condições impostas, as respectivas áreas deverão ser desapropriadas, passando ao domínio público.

No caso das unidades de uso sustentável, algumas espécies poderão ser constituídas por bens públicos ou privados ${ }^{65}$, e outras apenas por bens públicos ${ }^{66}$, variando suas diversas espécies previstas na lei em razão dos graus de condicionamento opostos ao titular da propriedade, a extensão da área protegida, assim como suas características.

\footnotetext{
${ }^{62}$ São espécies de unidades de proteção integral (artigo $\left.8^{\circ}\right)$ : I - Estação Ecológica; II - Reserva Biológica; III - Parque Nacional; IV - Monumento Natural; V - Refúgio de Vida Silvestre.

${ }^{62}$ São espécies de unidades de preservação permanente (artigo 14): I - Área de Proteção Ambiental; II Área de Relevante Interesse Ecológico; III - Floresta Nacional; IV - Reserva Extrativista; V - Reserva de Fauna; VI - Reserva de Desenvolvimento Sustentável; e VII - Reserva Particular do Patrimônio Natural. ${ }^{64}$ Artigos $12, \$ 1^{\circ}$ e $13, \$ 1^{\circ}$, da Lei Federal $n^{\circ} 9985 / 2000$.

${ }^{15}$ Será o caso das Áreas de Preservação Permanente (artigo 15), das Áreas de Relevante Interesse Ecológico (art. 16) e das Reservas Particulares do Patrimônio Natural (art. 21)

${ }^{66}$ Serão constituídas apenas de bens públicos, que quando for o caso, irão adquirir esta qualidade por intermédio de desapropriação as seguintes unidades de conservação: Floresta Nacional (art.17), Reserva Extrativista (art. 18), Reserva de Fauna (art. 19), e a Reserva de Desenvolvimento Sustentável (art. 20).
} 
Em relação às áreas de conservação que permanecem sob titularidade privada, a intervenção direta no direito de uso do proprietário (ius utendi), é a prerrogativa mais atingida em face da limitação do direito do titular da propriedade. Neste caso, note-se que o regime das unidades de conservação admite tanto o uso indireto como o uso direto do mesmo. O primeiro, caracterizado como "aquele que não envolve consumo, coleta, dano ou destruição dos recursos naturais" (artigo $2^{\circ}, \mathrm{IX}$ ). E o uso direto, como "aquele que envolve coleta e uso, comercial ou não, dos recursos naturais" (artigo $2^{\circ}, \mathrm{X}$ ). Neste sentido, propõe uma terceira categoria, de uso sustentável, nos seguintes termos: "exploração do ambiente de maneira a garantir a perenidade dos recursos ambientais renováveis e dos processos ecológicos, mantendo a biodiversidade e os demais atributos ecológicos, de forma socialmente justa e economicamente viável" (artigo $2^{\circ}$, inciso XI).

A definição de cada um desses usos, de sua vez, terá lugar nas definições constantes do plano de manejo $o^{67}$, igualmente definido na lei ${ }^{68}$. Este compõe-se de duas partes, uma vinculada às disposiçõcs da lei $\mathrm{e}$ da Constituição. Outra, discricionária, indicada à atuação do agente público segundo seu próprio entendimento ou, quando previsto em lei, decorrente da manifestação dos interessados em audiência pública. Em qualquer caso, entretanto, estarão submetidas aos princípios da razoabilidade e proporcionalidade entre a restrição imposta e o objetivo de interesse público perseguido - no caso, a preservação do meio ambiente.

Outra restrição típica das unidades de conservação, por expressa previsão legal (com exceção das áreas de proteção ambiental e das reservas particulares do patrimônio natural) é a constituição das zonas de amortecimento, consistente em área que permita a separação gradativa entre o meio ambiente antropicamente trabalhado e o meio ambiente natural, ou seja, um espaço destinado a diminuir ou enfraquecer os efeitos das atividades existentes na área circundante de uma unidade de conservação ${ }^{69}$. A adoção e implantação destas zonas de amortecimento, contudo, não podem desconhecer o uso legítimo que antes da instituição da área nela realizavam os titulares da propriedade sobre os bens imóveis integrantes da mesma. No caso, a restrição ao uso do bem não pode ser tal que caracterize a eliminação deste, sob pena de retirar o conteúdo econômico da exploração da propriedade sem qualquer espécie de compensação. Em casos nos quais a instalação da zona de amortecimento não admite a coexistência entre o uso econômico do bem e sua afetação a finalidade pretendida pelo Poder Público, a opção deve ser pela desapropriação da área ${ }^{70}$.

${ }^{67}$ Segundo Paulo Affonso Leme Machado, "o plano de manejo, na prática, será a lei interna das unidades de conservação". MACHADO, Paulo Affonso Leme. Áreas protegidas: a Lei nº 9985/2000. In: BENJAMIN. Direito ambiental das áreas protegidas..., op.cit., p. 248-275.

${ }^{68}$ Artigo 20, inciso XVII: "Plano de manejo: documento técnico mediante o qual, com fundamento nos objetivos gerais de uma unidade de conservação, se estabelece o seu zoneamento e as normas que devem presidir o uso da área e o manejo dos recursos naturais, inclusive a implantação das estruturas físicas necessárias à gestão da unidade"

${ }^{69}$ MACHADO, Paulo Affonso Leme. Áreas protegidas..., p. 2.58.

${ }^{70}$ No mesmo sentido é o entendimento de Paulo Affonso Leme Machado. Idem, p. 259. 
De modo geral, sempre quando o Estado, com a finalidade de preservação do meio ambiente, limitar em tal grau que caracterize a própria eliminação de uma das prerrogativas da propriedade - uso, gozo ou disposição - não se estará propriamente a impor deveres ao titular da propriedade, mas sim retirando parcela do direito. Razão pela qual a hipótese aí será de desapropriação e não propriamente da exigência de deveres inerentes ao domínio em face do dever geral de proteção ambiental.

Outra coisa, certamente, são os limites ou deveres impostos com a finalidade de preservação ambiental que impõe condutas, representadas por deveres de prestação ou abstenção do titular da propriedade. Em tais casos, o que estará sendo estabelecido, muitas vezes, são critérios de regularidade do exercício da propriedade, em face de deveres concretamente estabelecidos. É o caso, por exemplo, dos deveres impostos ao proprietário pelo Código Florestal (Lei Federal n ${ }^{\circ} 4.771$, de 15 de setembro de 1965), o qual em seu artigo $1^{\circ}$, parágrafo único, determina expressamente que "as ações ou omissões contrárias às disposiçôes deste Código na utilização e exploração das florestas são consideradas uso nocivo da propriedade". Remete-se neste caso, ao conceito típico de direito civil, de uso nocivo, mau uso ou abuso do direito de propriedade, o que pela lógica submete o proprietário às sançóes de estilo em face do mau exercício do direito.

E em relação ao Código Florestal, note-se que sua principal característica é a imposição de um dever de abstenção do proprietário, consistente na manutenção de áreas de floresta nos limites territoriais que estabelece $a$ prior $^{71}$, ou ainda nas situações específicas que menciona, quando a extensão destes limites será estabelecida por ato do Poder Público ${ }^{72}$. Assim como

${ }^{71}$ Assim o artigo $2^{\circ}$ do Código Florestal: "Art. $2^{\circ}$ Consideram-se de preservação permanente, pelo só efeito desta Lei, as florestas e demais formas de vegetação natural situadas: a) ao longo dos rios ou de qualquer curso d’água desde o seu nível mais alto em faixa marginal cuja largura mínima será: 1 - de 30 (trinta) metros para os cursos d'água de menos de 10 (dez) metros de largura; 2 - de 50 (cinqüenta) metros para os cursos d'água que tenham de 10 (dez) a 50 (cinqüenta) metros de largura; 3 - de 100 (cem) metros para os cursos d'água que tenham de 50 (cinqüenta) a 200 (duzentos) metros de largura; 4 - de 200 (duzentos) metros para os cursos d'água que tenham de 200 (duzentos) a 600 (seiscentos) metros de largura; 5 - de 500 (quinhentos) metros para os cursos d'água que tenham largura superior a 600 (seiscentos) metros; b) ao redor das lagoas, lagos ou reservatórios d'água naturais ou artificiais; c) nas nascentes, ainda que intermitentes e nos chamados "olhos d'água", qualquer que seja a sua situação topográfica, num raio mínimo de 50 (cinqüenta) metros de largura; d) no topo de morros, montes, montanhas e serras; e) nas encostas ou partes destas, com declividade superior a $45^{\circ}$, equivalente a $100 \%$ na linha de maior declive; f) nas restingas, como fixadoras de dunas ou estabilizadoras de mangues; g) tras bordas dos tabuleiros ou chapadas, a partir da linha de ruptura do relevo, em faixa nunca inferior a 100 (cem) metros em projeções horizontais; h) em altitude superior a 1.800 (mil e oitocentos) metros, qualquer que seja a vegetação."

${ }^{72}$ Art. $3^{\circ}$ - Consideram-se, ainda, de preservação permanentes, quando assim declaradas por ato do Poder Público, as florestas e demais formas de vegetação natural destinadas: a) a atenuar a erosão das terras; b) a fixar as dunas; c) a formar faixas de proteção ao longo de rodovias e ferrovias; d) a auxiliar a defesa do território nacional a critério das autoridades militares; e) a proteger sítios de excepcional beleza ou de valor científico ou histórico; f) a asilar exempiares da fauna ou flora ameaçados de extinção; g) a manter o ambiente necessário à vida das populações silvícolas; $h$ ) a assegurar condições de bem estar 
na denominada área e reserva legal ${ }^{73}$, situação em que se exige, inclusive, a respectiva averbação à margem do registro imobiliário para efeito de sua caracterização, assim como para impedir a alteração da sua destinação, pela qual são restringidas do proprietário as prerrogativas de uso e gozo do bem.

Da mesma forma, por ato do Poder Público outras restrições ao exercício da propriedade serão estabelecidas em face da preservação do meio ambiente, como é o caso do direito de usar a área para pastoreio ou decidir as técnicas que devem ser adotadas para fim do controle de pragas ${ }^{74}$. E a possibilidade de declarat-se como imune de corte determinadas espécies de árvores ${ }^{75}$, retirando do proprietário a possibilidade de fazề-lo, ainda que a rigor, sejam as mesmas de sua propriedade, na qualidade de bens imóveis por acessão.

Em relação ao direito de percepção dos frutos da coisa (ius fruendi), são várias as disposições de restrição ou controle do comércio e do uso industrial das espécies vegetais das florestas ${ }^{76}$, assim como, em certos casos, a obrigação do plantio de novas áreas ${ }^{77}$.

Em todas estas situações, em que a restrição parcial de uma ou mais prerrogativas da propriedade não a desnaturam como tal, o que se estabelece a rigor são deveres jurídicos para o exercício do direito, tal qual hoje é expressamente previsto na definição legal do artigo 1228, $\$ 1^{\circ}$. E na medida que a própria definição legal de propriedade autoriza a imposição de deveres jurídicos específicos para seu exercício de modo que sejam preservados, de conformidade como estabelecido em lei especial, a flora, a fauna, as belezas naturais, o equilíbrio ecológico e o patrimônio bistórico e artístico, ao estabelecer a lei especial uma série de deveres que regulam este exercício de direito, tais não podem ser indicadas como interferência no direito de propriedade, mas sim, regulação do seu exercício.

Todas estas situações, como se vê, serão de extrema relevância, e uma vez confrontadas à definição legal de propriedade, deverão ser caracterizadas ou não como limitação/restrição ao direito, cuja conclusão remeterá a qualidade em que serão admitidas pelo direito, assim como suas respectivas conseqüências.

\subsection{Deveres do proprietário e o direito de indenização.}

Ao direito de propriedade, além dos poderes jurídicos sobre a coisa, também se reconhecem quaisquer direitos ou pretensões à indenização em face da intromissão indevida na esfera jurídica do titular do direito ${ }^{78}$. A rigor, o direito à indenização é o corolário do

público. $\ 1^{\circ}$ A supressão total ou parcial de florestas de preservação permanente só será admitida com prévia autorização do Poder Executivo Federal, quando for necessária à execução de obras, planos, atividades ou projetos de utilidade pública ou interesse social."

${ }_{73}$ Artigo 16, do Código Florestal.

${ }^{74}$ Artigo $4^{\circ}$, do Código Florestal.

$7^{75}$ Artigo $7^{\circ}$, do Código Florestal.

${ }^{76}$ Artigos 12 e 13 do Código Florestal.

${ }_{77}$ Artigos 20 e 21 do Código Florestal.

${ }^{74}$ Assim: PONTES DE MIRANDA. Tratado de direito privado, v. 11, p. 13-14. 
direito de propriedade, porquanto se admite que da retirada das suas condições de proveito econômico seja reconhecida ao titular lesado a correspondente reparação pelo prerrogativa que se lhe retira. A Constituição da República asscgura, nas hipóteses de desapropriação ${ }^{79}$, a exigência de prévia e justa indenização do particular, no que se presume de iure o dano. Em outras hipóteses, como a utilização do bem pelo Poder Público em caso de perigo iminente, admitirá a indenização apenas na hipótese de existir dano ${ }^{80}$.

Entretanto, é necessário precisar conceitos, sobretudo naquilo que nos propomos neste estudo, em face do $\$ 1^{\circ}$ do artigo 1228 do Código Civil. A indenização pressupõe, conceitualmente, a existência de uma lesão a direito, razão pela qual, inclusive, discute-se em termos de responsabilidade civil, sua própria finalidade, se de reparação do valor de uma perda patrimonial, ou da soma necessária para recolocação do bem no estado anterior à lesão ${ }^{81}$. No caso da indenização por parte do Poder Público, em face de sua interferência no direito dos particulares, esta nem sempre se dá em face de um ilícito, senão muitas vezes por conta de uma perda econômica decorrente da atuação lícita do Estado (jus imperii), em favor de um determinado interesse público que - no caso - sobrepõe-se a certo interesse particular. Continua exigindo, contudo, a lesão a interesse/direito subjetivo protegido pela ordem juridica, o que no caso importa na interferência em poderes jurídicos, qualificados como tais, de modo a retirar-lhe suas características e possibilidades de fruição e proveito.

A proteção que a ordem jurídica brasileira indica ao meio ambiente, entretanto, impõe sensíveis alterações no conceito de dano indenizável em algumas searas das intervenções estatais na propriedade particular. Conforme ensina Paulo Affonso Leme Machado, com fundamento no artigo 45 da Lei n ${ }^{\circ} 9985 / 2000$, esta norma "deu novas orientações relativas à regularização fundiária das unidades de conservação, excluindo-se das indenizações, derivadas ou não de desapropriação: as espécies arbóreas declaradas imunes de corte pelo Poder Público; as expectativas de ganhos e lucro cessante; o resultado de cálculo efetuado mediante a operação de juros compostos e as áreas que não tenham prova de domínio inequívoco anterior à criação das áreas de conservação"

A rigor, o ponto central da controvérsia é a identificação do que se trata de efetiva interferência que causa lesão aos direitos do proprietário, e o que se caracteriza como imposição de deveres jurídicos decorrentes da própria definição jurídica de propriedade, decorrentes de sua função social e consignados como pautas do exercício do direito.

${ }^{79}$ Artigos $5^{\circ}$, inciso XXIV, 182, $\$ 3^{\circ}$ e 184 da Constituição da República. Em outros casos, como as que a desapropriação caracteriza-se como sanção de ilícito, descabe exigir-se indenização, como o previsto no artigo 243, do ADCT em relação às glebas onde forem localizadas culturas ilegais de plantas psicotrópicas.

${ }^{80}$ Artigo 5०, inciso XXV: "no caso de iminente perigo público, a autoridade competente poderá usar de propriedade particular, assegurada ao proprietário indenização ulterior, se houver dano".

${ }^{81}$ Sobre o tema veja-se: VINEY, Geneviève; JOURDAIN, Patrice. Les effets de la responsabilité. In: GHESTIN, Jacques (Directeur). Traité de droit civil. $2^{2}$ ed. Paris: LGDJ, 2001, p. 183 et seq.

${ }^{82}$ MACHADO, Paulo Affonso Leme. Áreas protegidas..., p. 257. 
Outra questão colocada por Antônio Herman Benjamin é a da exigência ou não da indenização, na hipótese de determinat-se a conservação das áreas de preservação permanente e das reservas florestais legais, assim como sua consideração para efeitos de cálculo do quantum indenizatório na hipótese de ulterior desapropriação direta ou indireta. Parte então, do pressuposto com o qual concordamos, de que "a obrigação de resguardar o meio ambiente não infringe o direito de propriedade, não ensejando desapropriação" em tais casos não há inviabilidade do exercício da propriedade, mas apenas sua limitação, nos termos da lei. Por essa razão, defende na hipótese de desapropriação do imóvel em que estejam presentes áreas de preservação permanente, e de reserva florestal legal, que estas sejam afastadas para fins de cálculo do valor do imóvel com vistas à indenização ${ }^{84}$.

Em exame da jurisprudência do Superior Tribunal de Justiça observam-se decisões, em matéria de desapropriação, nas quais se reconhece que a cobertura vegetal das áreas de preservação permanente, definidas como tal pelo Código Florestal, não são suscetíveis de indenização ${ }^{85}$. Todavia, nas hipóteses em que se caracteriza a supressão do direito de uso e fruição do bem pela imposição de deveres de preservação, há decisões em sentido diverso, pela procedência do pleito indenizatório ${ }^{86}$.

É fato que a influência dos preceitos de direito ambiental - a partir das normas constitucionais que lhe fundamentam - sobre o direito civil, vem provocando uma série de modificações no modo de conceber e interpretar os conceitos jurprivatísticos. Um exemplo interessante neste sentido é a natureza que se vem reconhecendo a obrigação de recomposição do ambiente degradado em razão de dano ambiental pelos tribunais, a qual vem se reconhecendo como espécie de obrigação propter rem, uma vez que acompanha a coisa para ser imposta ao titular da mesma, na hipótese de transmissão da propriedade ${ }^{87}$.

No caso do direito à indenização, é fora de dúvida que a garantia do proprietário de, na hipótese de lhe ser retirado o conteúdo econômico do seu direito, fazer jus à respectiva compensação, deve ser interpretada em conformidade com significado da propriedade que indica o Código Civil. E neste caso, vai exigir do intérprete uma postura científica própria para identificar, dentre os condicionamentos impostos pela Constituição e pela legislação ordinária

83 BENJAMIN. Desapropriação, reserva florestal legal..., p. 37.

${ }^{84}$ Idem, p. 40.

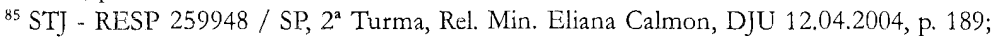

${ }^{86}$ ST'J - RESP 188781 / PR, 1 Turma, Rel. Min. Humberto Gomes de Barros, DJU 29.11.1999, p. 125.

${ }^{87}$ ADMINISTRATIVO - DANO AO MEIO-AMBIENTE - INDENIZAÇÃO - LEGITIMAÇÃO PASSIVA DO NOVO ADQUIRENTE. 1. A responsabilidade pela preservação e recomposição do meioambiente é objetiva, mas se exige nexo de causalidade entre a atividade do proprietário e o dano causado (Lei 6.938/81). 2. Em se tratando de reserva florestal, com limitação imposta por lei, o novo proprietário, ao adquirir a área, assume o ônus de manter a preservação, tornando-se responsável pela reposição, mesmo que não tenha contribuído para devastá-la. 3. Responsabilidade que independe de culpa ou nexo causal, porque imposta por lei. 4. Recursos especiais providos em parte. (STJ - RESP

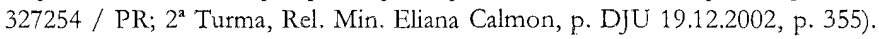


que lhe fundamenta, o que representará restrição ao direito - indenizável na forma da lei - e o que consistirá em simples imposição de dever jurídico, à luz do disposto no artigo 1228, $\$ 1^{\circ}$ do Código Civil. Neste último caso, uma vez que se tratam de deveres inerentes ao exercício do direito de propriedade, não destacam/afetam seu conteúdo e, portanto, serão insuscetíveis de indenização.

\section{CONCLUSÕES}

A transformação histórica da definição de propriedade em direito ordinário, e sua elevação à qualidade de direito fundamental, demonstra um traçado que remete de um poder jurídico pleno exercido segundo à vontade do titular do direito, até sua conformação como prerrogativa indicada a certos fins sociais e econômicos aos quais vinculam-se os titulares deste poder. Igualmente, os conceitos técnico-jurídicos que lhe são correlatos, como a distinção entre titularidade exercício de direitos, e a possibilidade de limitação e sanção do abuso em relação a este último, assim como a eleição de novos bens da vida dignos de proteção jurídica e, logo, oponíveis desde logo ao poder jurídico do proprietário, exigem um novo modo de interpretar-se a propriedade. Uma nova mentalidade sobre a propriedade, retomando o pensamento de Paolo Grossi ${ }^{88}$.

A relativização dos direitos subjetivos, a revalorização do interesse social frente a propriedade, as questões urbana e agrária, e a exigência de ações para seu enfrentamento, um novo enfoque sobre a função jurídica da posse e, afinal, a crescente tutela jurídica do meio ambiente, alteraram substancialmente o modo como o direito passa a interpretar o conceito de propriedade. Neste caminho, todos esses interesses protegidos juridicamente, assim como outros aqui não mencionados, em regra foram colocados como contrapostos à proteção jurídica da propriedade, de modo que a solução destes "conflitos" realizava-se mediante uma composição ou coordenação de interesses, no mais das vezes, afastando-se parte do conteúdo de ambos os direitos para alcançar-se um ponto de equilíbrio. Ou seja, a postura do jurista era de identificá-los como elementos distintos que, encontrando-se em dada relação jurídica por expressa determinação constitucional ou legal, deveriam alcançar um nível de interação que, afinal, preservasse a essência de ambos os interesses.

Ocorre que neste raciocínio, a propriedade --ainda que de modo disfarçado ou implícito - conservava seu caráter absoluto do direito civil clássico. Tudo o que fosse representativo de um mínimo de deveres jurídicos, sobretudo os de abstenção oponíveis ao titular do direito subjetivo, deveria ser devidamente compensado, ou exigido desde logo a perda da propriedade por desapropriação - sempre com vistas à indenização. Não se vislumbrava assim, a possibilidade de deveres inerentes ao próprio conteúdo da propriedade, ainda que os

${ }^{8 B}$ GROSSI, Paolo. La propriedad y las propriedades..., op. cit., p. 58. 
antecedentes históricos mais recentes, sobretudo em direito comparado, indicassem nesta direção, como é o caso mais célebre da Constituição alemã de 1919, e sua idéia-força de que " $a$ propriedade obriga".

É aí que a alteração da definição legal de propriedade, hoje prevista no artigo 1228 do Código Civil permite um elemento a mais, decisivo até na postura do intérprete mais resistente às transformações conceituais que mencionamos. Com o novo Código Civil o conceito em direito ordinário da propriedade se altera. A partir dele, não se trata apenas do direito usar, gozar e dispor da coisa, e de reavê-la de quem quer que injustamente a possua ou detenha, mas é também isto. Inclui-se contudo, restrições ao poder disposição do proprietário e, no que interessa a esse trabalho, a definição de pautas de conduta exigíveis do titular do direito, consistente na imposição de novos deveres jurídicos. Tais deveres não consistem em limitações ou restrições ao direito, mas sim conformam o direito, que se reconhecerá legítimo e jurídico, apenas na hipótese de respeitar os deveres ali consignados.

No caso dos deveres de preservação ambiental, a definição jurídica de propriedade expressamente remete à legislação especial sua determinação específica, o que naturalmente permite concluir que o cumprimento dos mesmos, tais como estabelecidos nas normas próprias, será condição de reconhecimento do exercício regular do direito. Neste sentido, suprime-se a noção de "conflito" entre a propriedade e as exigências de preservação do meio ambiente, no que se refere a eventuais limitações dos poderes do proprietário. Não serão mais limitações, com o caráter restritivo que carrega a expressão, mas deveres de conformação da propriedade, atinentes ao exercício do direito, razão pela qual não poderão ensejar considerações acerca da perda injusta de qualquer das prerrogativas do domínio. Ao contrário, as noções de propriedade e domínio sim, é que incorporam tais deveres de conformação atribuidos a seus titulares. Razão pela qual é possível concluir que, tal qual está presente em nossa legislação civil, o artigo 1228 do Código Civil provoca alteração substantiva da definição de propriedade em nosso direito ordinário, e por conseqüência, na própria interpretação das normas constitucionais. 